\begin{tabular}{|c|c|c|c|c|c|}
\hline JRL & Vol. 12 & No. 1 & Hal : $15-40$ & $\begin{array}{c}\text { Jakarta, } \\
\text { Juni } 2019\end{array}$ & $\begin{array}{c}\text { p-ISSN : } 2085.38616 \\
\text { e-ISSN : 2580-0442 }\end{array}$ \\
\hline
\end{tabular}

\title{
GREEN TECHNOLOGY UNTUK GREEN COMPANY DENGAN PENERAPAN SISTEM FOTOBIOREAKTOR PENYERAP KARBON DIOKSIDA
}

\author{
Fuzi Suciati, Dwindrata B. Aviantara \\ Pusat Teknologi Lingkungan - BPPT \\ Gd. 820 Geostech PUSPIPTEK Serpong, 15314, Provinsi Banten \\ 1Penulis korespondensi: fuzi.suciati@gmail.com
}

\begin{abstract}
Abstrak
Indonesia telah menandatangani kesepakatan internasional Kyoto Protocol dalam upaya turut serta berkontribusi dalam mitigasi pemanasan global. Melalui dokumen Nationally Determined Contribution (NDC) Indonesia berkomitmen untuk menurunkan emisi karbon sebesar 29\% pada tahun 2030 secara mandiri atau sebesar $41 \%$ bila mendapat dukungan internasional. Fotobioreaktor merupakan sistem yang dapat diterapkan dalam upaya menahan jumlah karbon dioksida yang dilepas melalui cerobong industri ke udara. Dengan mengumpankan gas karbondioksida yang diemisikan oleh cerobong ke dalam sistem fotobioreaktor di mana mikroalga ditumbuhkan maka alih-alih gas karbon dioksida di lepas ke udara dapat digunakan sebagai sumber karbon bagi mikroalga untuk bertumbuh dan berkembang. Penerapan teknologi fotobioreaktor dapat meningkatkan citra perusahaan sebagai Perusahaan Hijau yang memberikan daya ungkit selain kinerja lingkungan perusahaan juga potensi mendapatkan insentif ekonomi melalui Mekanisme Pembangunan Bersih. Meski demikian masih terdapat tantangan besar dalam penerapan fotobioreaktor mikroalga untuk mitigasi emisi karbon dioksida. Selain kendala dalam teknik pemanenan mikroalga juga keterbatasan laju serapan karbon dioksida oleh mikroalga.
\end{abstract}

Kata kunci : fotobioreaktor, perusahaan hijau, mikroalga, karbon dioksida

Green Technology Untuk.... JRL. Vol. 12 No. 1, Juni - 2019 : 14 - 40 


\title{
GREEN TECHNOLOGY FOR GREEN COMPANY THROUGH THE APPLICATION OF PHOTOBIOREACTOR SYSTEM AS CARBON DIOXIDE ABSORBER
}

\begin{abstract}
Indonesia has signed international agreement Kyoto Protocol to involve and contribute to mitigation of global warning. As stated in Nationally Determined Contribution (NDC) document, by 2030, Indonesia committed to reduce carbon emission at level $29 \%$ by independent efforts or at level $41 \%$ by international supports. Photobioreactor is a system that can be applied in effort to reduce emitted carbon dioxide into the atmosphere by industrial stacks. The emitted carbon dioxide gas is fed into a photobioreactor where microalgae is grown. Thus, instead of emitted into the atmosphere the catbon dioxide is used as carbon source for microalgae to proliferate. The application of photobioreactor technology could improve image of companies as a Green Company. In addition to improve environmental performance of the company such the implementation could also provide economical incentive through Clean Development Mechanism. Nevertheless, the stil exist prominent obstacles to implement the microalgae photobioreactor technology in carbon dioxide mitigation are harvesting technique and limited absorption rates of carbon dioxide by microalgae.
\end{abstract}

Keywords: photobioreactor, green company, microalgae, carbon dioxide 


\section{PENDAHULUAN}

Pemanasan global (global warming) merupakan persoalan dunia yang telah menjadi perbincangan antar negara sejak tahun 1979 hingga mencetuskan kesepakatan internasional Climate Change Convention pada tahun 1992 yang kemudian berlanjut dengan dibuatnya kesepakatan internasional Kyoto Protocol pada tahun 1997. Kesepakatan tersebut didasarkan atas pengukuran suhu global yang cenderung terus meningkat sejak 1880an sebagaimana ditunjukkan pada Gambar 1 . Kenaikan tersebut diduga berkaitan dengan konsentrasi sejumlah kontaminan di atmosfer, khususnya gas rumah kaca (greenhouse gases) seperti gas lemas atau karbon dioksida $\left(\mathrm{CO}_{2}\right)$, metana $\left(\mathrm{CH}_{4}\right)$, gas tawa atau nitro oksida $\left(\mathrm{N}_{2} \mathrm{O}\right)$, ozon $\left(\mathrm{O}_{3}\right)$, bahkan uap air $\left(\mathrm{H}_{2} \mathrm{O}\right)$. Keberadaan gas tersebut di atmosfer menyebabkan suhu permukaan bumi menjadi hangat karena kemampuan gas tersebut menyerap tenaga panas dari pantulan gelombang elektromagnetik (inframerah) sinar matahari. Tanpa adanya gas rumah kaca (GRK) tersebut diperkirakan suhu permukaan bumi adalah $-18^{\circ} \mathrm{C}$ sehingga tidak cocok untuk kehidupan manusia dan biota. Meningkatnya populasi penduduk dunia memicu pemenuhan kebutuhan pangan, sandang dan papan dari waktu ke waktu dengan ditopang oleh perkembangan ilmu pengetahuan dan teknologi. Jumlah penduduk dunia telah bertumbuh dari sekitar 1 milyar pada tahun 1800 menjadi 7,4 milyar pada 2015 dan diperkirakan mencapai 11,2 milyar pada tahun 2100 (Roser \& Ortiz-Ospina 2017). Dengan semakin intensive- dan extensivenya manusia mengekspolitasi sumberdaya alam untuk pemenuhan kebutuhan ternyata telah diyakini memberikan dampak terhadap perubahan keadaan lingkungan. Berawal dari revolusi industri pada tahun 1750 kegiatan anthropogenic diperkirakan telah meningkatkan konsentrasi karbon dioksida sebesar $45 \%$, dari 280 ppm pada tahun 1750 menjadi 405 ppm pada tahun 2018 (Global Greehouse Gas Reference Network, 2018). Peningkatan konsentrasi karbon ini beserta sejumlah gas rumah kaca lainnya (Gambar 2) selaras dengan peningkatan suhu global yang berpotensi mengancam keberlangsungan kehidupan alam termasuk manusia

Dampak pemanasan global yang timbul di antaranya adalah perubahan biosfer yang dapat menyebabkan kepunahan sejumlah spesies dan 
berakibat menurunnya keanekaragaman hayati. Selain itu juga dapat meningkatkan muka air laut akibat mencairnya gunung es di kutub bumi sehingga berisiko menenggelamkan sejumlah negara di wilayah pasifik. Sebagai negara kepulauan yang berciri nusantara dan mempunyai garis pantai terpanjang kedua di dunia, dengan jumlah penduduk yang besar dan kemampuan ekonomi yang terbatas, Indonesia berada pada posisi yang sangat rentan terhadap dampak perubahan iklim bagi lingkungan dan kehidupan bangsa Indonesia. Dampak tersebut meliputi turunnya produksi pangan, terganggunya ketersediaan air, tersebarnya hama dan penyakit tanaman serta manusia, naiknya permukaan laut, tenggelamnya pulau-pulau kecil, dan punahnya keanekaragaman hayati.

Menimbang dampak yang ditimbulkan oleh peningkatan gas rumah kaca di atmosfer tersebut Pemerintah Indonesia sebagai bagian dari komunitas global berkomitmen untuk turut menjaga agar penyimpangan suhu atmosfer tidak lebih dari $2^{\circ} \mathrm{C}$. Secara formal hal ini telah dilakukan oleh Pemerintah Indonesia dengan diterbitkannya Undang Undang Nomor 17 Tahun 2004 tentang Pengesahan Kyoto Protocol to the United Nations Framework Convention on Climate Change. Dalam komitmen tersebut Pemerintah Indonesia akan menurunkan emisi gas rumah kaca sebesar $26 \%$ terhadap emisi tahun 2030 jika tidak dilakukan mitigasi (business as usual) melalui upaya mandiri atau $41 \%$ melalui bantuan internasional. Protokol Kyoto bertujuan menjaga agar konsentrasi GRK di atmosfer berada pada tingkat yang tidak membahayakan sistem iklim bumi. Untuk mencapai tujuan itu, protokol tersebut mengatur pelaksanaan penurunan emisi oleh negara industri sebesar $5 \%$ di bawah tingkat emisi tahun 1990 melalui mekanisme Implementasi Bersama (Joint Implementation), Perdagangan Emisi (Emission Trading), serta Mekanisme Pembangunan Bersih (Clean Development Mechanism). Mekanisme Pembangunan Bersih (MPB) merupakan bentuk investasi baru di negara berkembang yang bertujuan mendorong negara industri untuk melaksanakan kegiatan penurunan emisi di negara berkembang guna mencapai target penurunan emisi GRK dan membantu negara berkembang untuk mencapai tujuan pembangunan berkelanjutan. Sejumlah negara maju (industri) yang tercantum dalam Annex 1 Kyoto Protocol yang telah lama menghasilkan emisi GRK dan terakumulasi di atmosfer dalam jumlah cukup besar berkewajiban menurunkan emisi GRK dan mengatasi dampak 
perubahan iklim. Sementara itu negara berkembang yang tidak berkewajiban menurunkan emisi GRK berhak mendapatkan bantuan dari negara industri dalam rangka berpartisipasi secara sukarela untuk menurunkan emisi GRK dan mengatasi dampak perubahan iklim

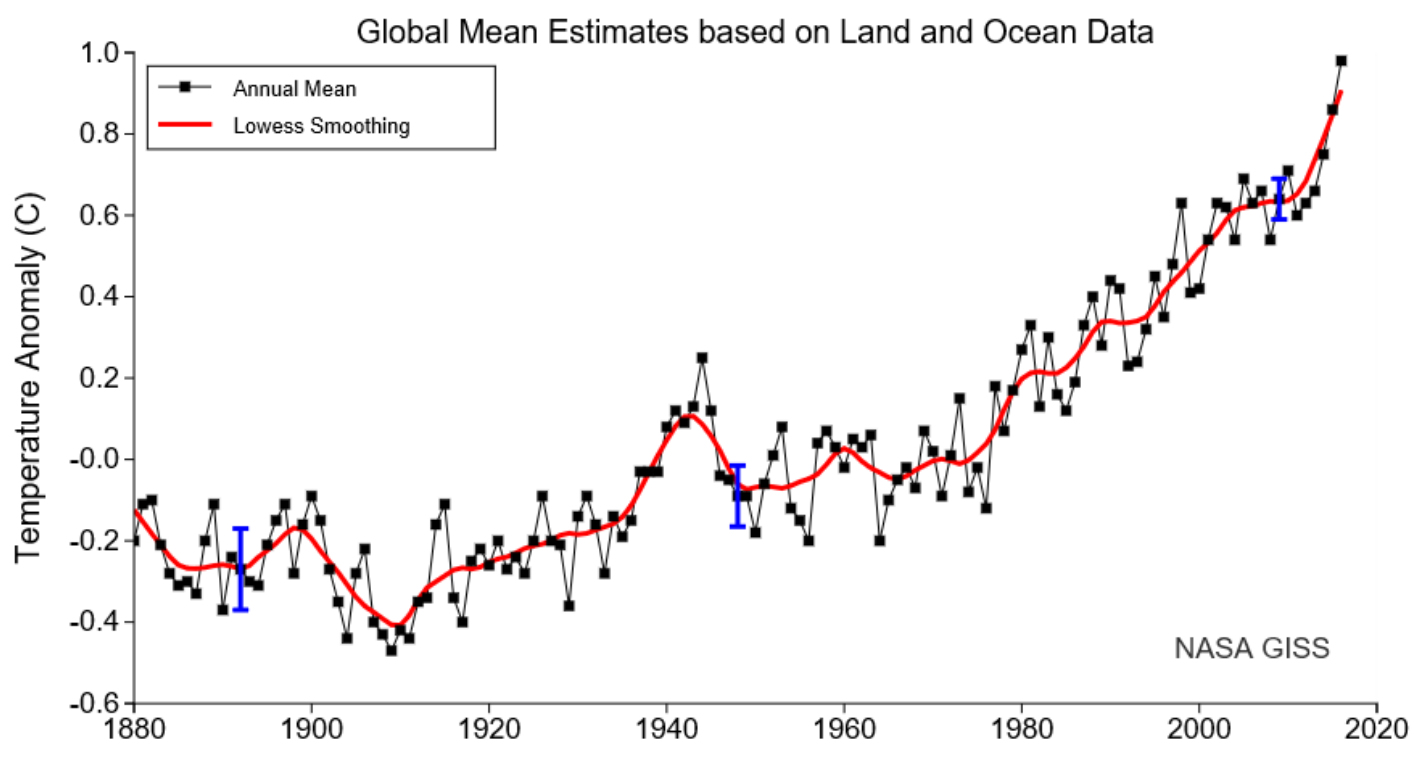

Gambar 1. Kecenderungan kenaikan suhu global periode 1880 - 2020

(Sumber: Wikipedia 2018a) 



197519801985199019952000200520102015

197519801985199019952000200520102015
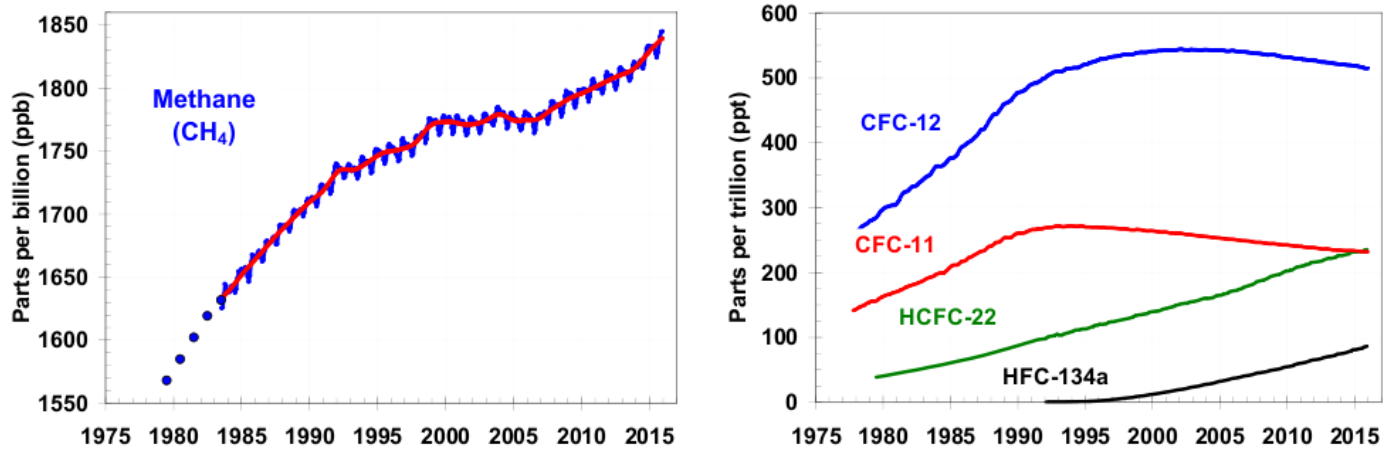

Gambar 2. Peningkatan konsentrasi gas rumah kaca periode 1980 - 2015

(Sumber: Wikipedia 2018b) 


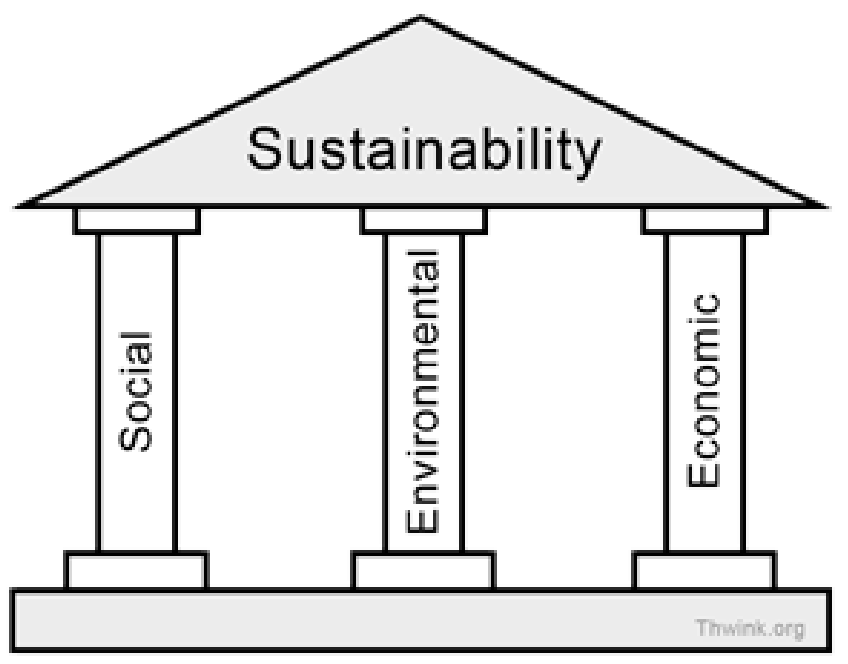

Gambar 3. Tiga pilar pembangunan berkelanjutan (Sumber: thwink.org, 2014)

\section{METODE}

Dalam menyusun makalah ini menggunakan metode penelusuran informasi sekunder yang diperoleh dari jurnal (nasional dan internasional), laporan teknis, textbook, buku pegangan (handbook) serta sejumlah sumber lainnya yang dapat diperoleh dari laman internet.

\section{HASIL DAN PEMBAHASAN}

\section{KONSEP PERUSAHAAN HIJAU}

Pada saat ini faktor lingkungan sebagai salah satu penopang pembangunan bahkan sebagai salah satu syarat kecukupan dalam kegiatan ekonomi telah diterima banyak pihak. Dalam paradigma pembangunan berkelanjutan (sustainable development) tiga pilar (sosial, ekonomi dan lingkungan) harus berperan bersama yang mana ketimpangan atau ketidakselarasan pada salah satu pilar atau lebih menyebabkan kegagalan pembangunan berkelanjutan sebagaimana diperlihatkan pada Gambar 3. Banyak konsep dikembangkan untuk menegakkan pilar lingkungan (environment) seperti konsumsi dan produksi berkelanjutan (sustainable consumption and production), produksi bersih (cleaner production), waste 
exchange atau waste to product, zero waste dan end of pipe. Yang terakhir, yakni end of pipe, merupakan konsep pengolahan limbah dan merupakan pilihan terakhir yang dianjurkan setelah konsep yang sebelumnya dipertimbangkan. Hal ini merupakan konsekuensi termodinamik yang menyatakan bahwa efisiensi tidak akan pernah mencapai $100 \%$. Oleh sebab itu dalam proses apapun limbah akan selalu tetap ada namun dapat diminimalkan.

Pemerintah Indonesia berupaya meningkatkan mutu lingkungan hidup Indonesia seiring dengan kegiatan ekonomi, khususnya industri. Melalui penerapan Peraturan Menteri Lingkungan Hidup Nomor 18 Tahun 2012 tentang Program Penilaian Peringkat Kinerja Perusahaan Dalam Pengelolaan Lingkungan Hidup atau disingkat PROPER pelaku usaha atau industri diwajibkan mengendalikan pencemaran dan/atau kerusakan lingkungan hidup serta melaksanakan pengelolaan limbah bahan berbahaya dan beracun (LB3). PROPER diterapkan melalui mekanisme insentif dan disinsentif berdasarkan penilaian terhadap kinerja perusahaan dalam pengendalian pencemaran lingkungan hidup, pengendalian perusakan lingkungan hidup serta pengelolaan limbah bahan berbahaya dan beracun). Kriteria PROPER terdiri dari dua bagian yaitu kriteria penilaian ketaatan dan kriteria penilaian lebih dari yang dipersyaratkan dalam peraturan (beyond compliance). Untuk penilaian kriteria ketaatan, aspek yang dinilai adalah ketaatan terhadap 5P yaitu (Portal Resmi Pemerintah Kabupaten Sukabumi, 2018):

a) Persyaratan dokumen lingkungan dan pelaporannya

b) Pengendalian pencemaran air

c) Pengendalian pencemaran udara

d) Peraturan pengelolaan limbah bahan berbahaya dan beracun (B3) dan

e) Potensi kerusakan lahan.

Untuk kriteria penilaian ketaatan akan selalu dilakukan pembaharuan dengan menerapkan peraturan-peraturan terbaru ke dalam kriteria. Sedangkan untuk kriteria penilaian aspek lebih dari yang dipersyaratkan (beyond compliance) lebih bersifat dinamis menyesuaikan dengan perkembangan teknologi, praktek pengelolaan lingkungan terbaik (Best Environmental Practices), dan isu-isu lingkungan yang bersifat global. Kriteria penilaian aspek lebih dari yang dipersyaratkan tersebut terdiri dari:

a) Sistem manajemen lingkungan

b) Pemanfaatan sumberdaya yang terdiri atas:

a. efisiensi energi

b. pengurangan dan pemanfaatan limbah bahan berbahaya dan beracun 
c. reduce, reuse, dan recycle (3R) limbah padat non bahan berbahaya dan beracun

d. pengurangan pencemar udara

e. konservasi dan penurunan beban pencemaran air

f. perlindungan keanekaragaman hayati

c) Pemberdayaan masyarakat dan

d) Penyusunan dokumen ringkasan kinerja pengelolaan lingkungan

Penilaian kinerja perusahaan atas pengelolaan lingkungan diberikan dalam bentuk peringkat kinerja yang terdiri atas (Kementerian Lingkungan Hidup dan Kehutanan, 2018):

a) EMAS yang diberikan kepada penanggung jawab usaha dan/atau kegiatan yang telah secara konsisten menunjukkan keunggulan lingkungan (environmental excellency) dalam proses produksi dan/atau jasa, melaksanakan bisnis yang beretika dan bertanggung jawab terhadap masyarakat

b) HIJAU yang diberikan kepada penanggung jawab usaha dan/atau kegiatan yang telah melakukan pengelolaan lingkungan lebih dari yang dipersyaratkan dalam peraturan (beyond compliance) melalui pelaksanaan sistem manajemen lingkungan, pemanfaatan sumberdaya secara efisien dan melakukan upaya pemberdayaan masyarakat dengan baik

c) BIRU yang diberikan kepada penanggung jawab usaha dan/atau kegiatan yang telah melakukan upaya pengelolaan lingkungan sesuai dengan persyaratan sebagaimana diatur dalam peraturan perundangundangan

d) MERAH yang diberikan kepada penanggung jawab usaha dan/atau kegiatan yang upaya pengelolaan lingkungan hidup dilakukannya tidak sesuai dengan persyaratan sebagaimana diatur dalam peraturan perundangundangan

e) HITAM yang diberikan kepada penanggung jawab usaha dan/atau kegiatan yang sengaja melakukan perbuatan atau melakukan kelalaian yang mengakibatkan pencemaran dan/atau kerusakan lingkungan serta pelanggaran terhadap peraturan perundang-undangan atau tidak melaksanakan sanksi administrasi.

Sebagai konsekuensi dari PROPER tersebut maka untuk perusahaan dengan kinerja lingkungan yang tergolong ke dalam peringkat BIRU, HIJAU dan EMAS akan mendapatkan sertifikat penghargaan dari Pemerintah Indonesia. Penghargaan tersebut akan memberi nilai tambah terhadap daya ungkit citra perusahaan dari 
unsur pengelolaan lingkungan. Untuk perusahaan besar hal ini akan memberikan dampak terhadap market share produk yang dihasilkan oleh perusahaan tersebut terutama bila produk tersebut diekspor ke negara maju yang mensyaratkan bahwa produk tersebut harus diproduksi dengan cara yang berwawasan lingkungan. Sedangkan konsekuensi dari PROPER untuk perusahaan yang masuk ke dalam peringkat MERAH dan HITAM akan dikenakan sanksi sesuai dengan peraturan perundang-undangan yang berlaku. Makalah ini memaparkan tentang penerapan konsep waste to product yang memberikan nilai tambah terhadap citra perusahaan menjadi lebih "green" dan berpotensi untuk menjadi daya ungkit untuk mendapatkan nilai PROPER yang lebih baik. Selain itu terbuka pula kemungkinan untuk mendapatkan insentif ekonomi melalui CDM, khususnya bilateral.

\section{FOTOBIOREAKTOR}

Seiring dengan meningkatnya konsentrasi $\mathrm{CO}_{2}$ antropogenik di atmosfer, berbagai upaya perekayasaan telah dilakukan untuk menangkap dan memendam $\mathrm{CO}_{2}$ atmosferik tersebut. Teknologi tersebut adalah carbon capture and storage (CCS) dengan sejumlah ragam teknik dalam melakukannya seperti penambatan (sequestration) $\mathrm{CO}_{2}$ ke dalam fluida yang kemudian dinjeksikan ke formasi geologik, penyerapan (absorption) $\mathrm{CO}_{2}$ dalam larutan kaustik dalam artificial tree, pengoksidasian $\mathrm{CO}_{2}$ menjadi senyawa lain melalui reaksi kimia serta proses fisika lainnya. Terdapat juga cara biologis yang disebut dengan biofiksasi dengan memanfaatkan mikroalga. Cara ini yang kemudian berkembang menjadi teknologi fotobioreaktor untuk menyerap karbon. Prinsipnya adalah proses biologis pertumbuhan biomassa alga yang mensyaratkan adanya sumber karbon sebagai salah satu komponen zat hara (nutrition) pembangun sel.

Fotobioreaktor (FBR) dapat berupa kolom tembus pandang (terbuat dari gelas, akrilik atau plastik) sebagaimana ditunjukkan pada Gambar 5 atau berupa kolam (baik tertutup maupun terbuka) sebagaimana ditunjukkan pada Gambar 6 yang di dalamnya terdapat medium di mana biota penyerap karbondioksida bertumbuh dan berkembang. Biota yang ada dalam medium tersebut adalah mikroalga, yakni mikrofita bersel tunggal. Karena merupakan mikrofita dengan kemampuan sebagai autotroph maka dalam sel sebuah mikrofita terdapat klorofil yang berperan dalam proses fotosintesis untuk mensintesis glukosa dari karbon dioksida dan air dengan bantuan sinar UV matahari. Berikut contoh visual dari mikroalga. 


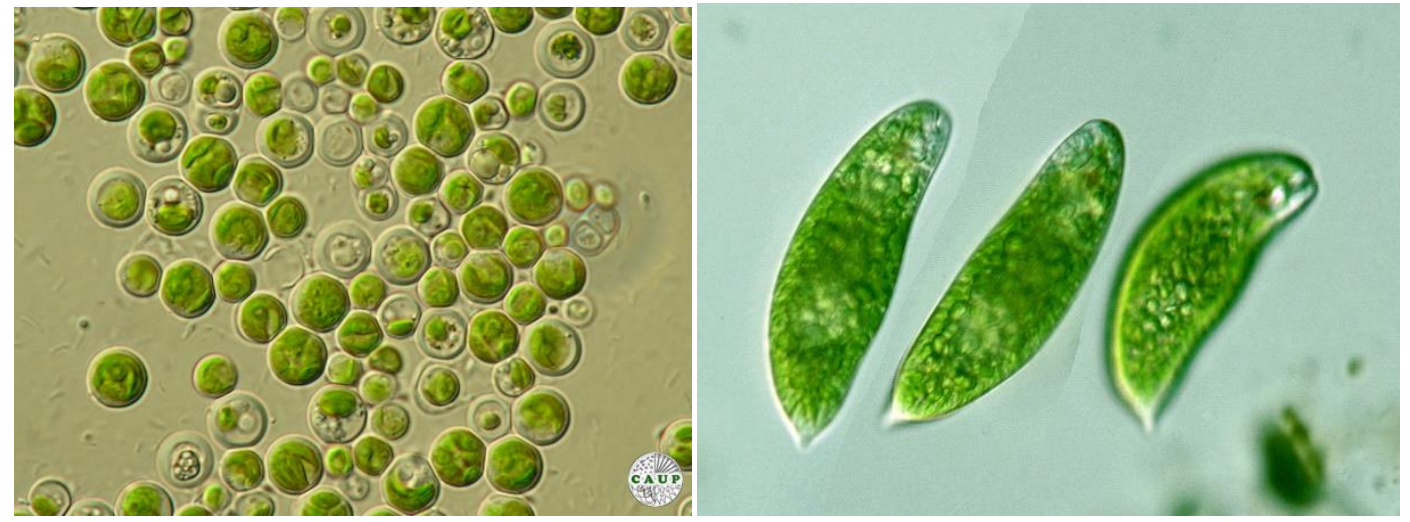

Gambar 4. Contoh visual mikroalga Chlorella vulgaris (kiri) dan Euglena sp (kanan)

Saat mikroalga bertumbuh dan berkembang dalam sistem FBR untuk membentuk biomassa yang lebih besar volume dan bobotnya maka terdapat kesetaraan dengan jumlah karbondioksida yang diserapnya. Penelitian yang dilakukan oleh team Badan Pengkajian dan Penerapan Teknologi (BPPT) dengan menggunakan berbagai spesies mikroalga menunjukkan bahwa mikrofita sangat berpotensi untuk menyerap karbon dioksida dan saat bersamaan berperan dalam finishing pengolahan air limbah (Mulyanto \& Handayani, 2015, Handayani et al., 2014; Santoso et al., 2012). Penelitian yang dilakukan telah mencapai tahap pilot plant yang berawal dari penelitian skala laboratorium (lab scale) dan diteruskan ke tahap skala bangku (bench scale). Skala pilot dilakukan pada perusahaan produksi minuman susu. Dalam proses produksi susu cair diperlukan tahap pemanasan sehingga untuk keperluan tersebut perusahaan mengoperasikan tiga buah ketel uap yang masing-masing mampu menghasilkan uap panas dengan kapasitas 5 ton/jam. Seluruh ketel uap tersebut berbahan bakar heavy oil. Bahan bakar tersebut harus disimpan pada suhu sekitar $38^{\circ} \mathrm{C}$ dan saat akan dipompa harus dipanaskan lebih lanjut hingga mencapai suhu dalam kisaran 66 $121^{\circ} \mathrm{C}$. Selama proses produksi dua dari tiga ketel uap tersebut dioperasikan secara 
bersamaan sedangkan satu ketel ini tidak ada peraturan yang membatasi dikondisikan pada keadaan stand by. lepasan karbondioksida ke udara. Namun Tekanan operasi dari tiap ketel uap dalam rangka membangun citra mencapai 8 bar. Suhu gas buang di ujung perusahaan agar lebih "green" maka menara yang tingginya $10 \mathrm{~m}$ dapat perusahaan tersebut akan mengelola mencapai $230^{\circ} \mathrm{C}$. Gas buang tersebut lepasan $\mathrm{CO}_{2}$ tersebut dengan merupakan sumber lepasan $\mathrm{CO}_{2}$ ke menggunakan sistem FBR. Gambar 5 atmosfer yang selama ini dipraktekkan oleh menyajikan diagram pilot scale sistem FBR perusahaan tersebut. Sampai dengan saat di perusahaan tersebut. 

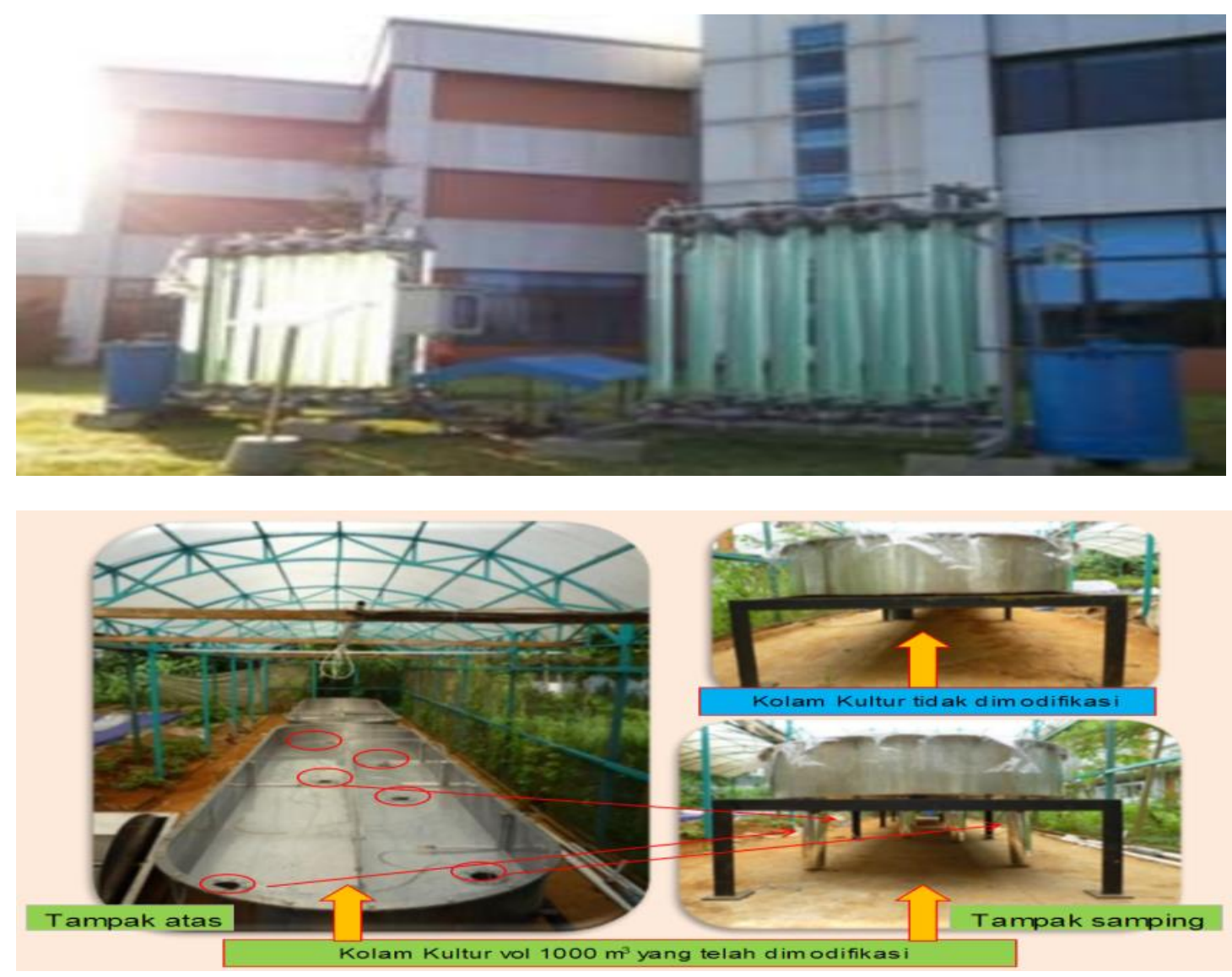

Gambar 5. Sistem FBR tipe tubular (atas) dan kolam raceway (bawah)

Green Technology Untuk.... JRL. Vol. 12 No. 1, Juni - 2019 : 14 - 40 


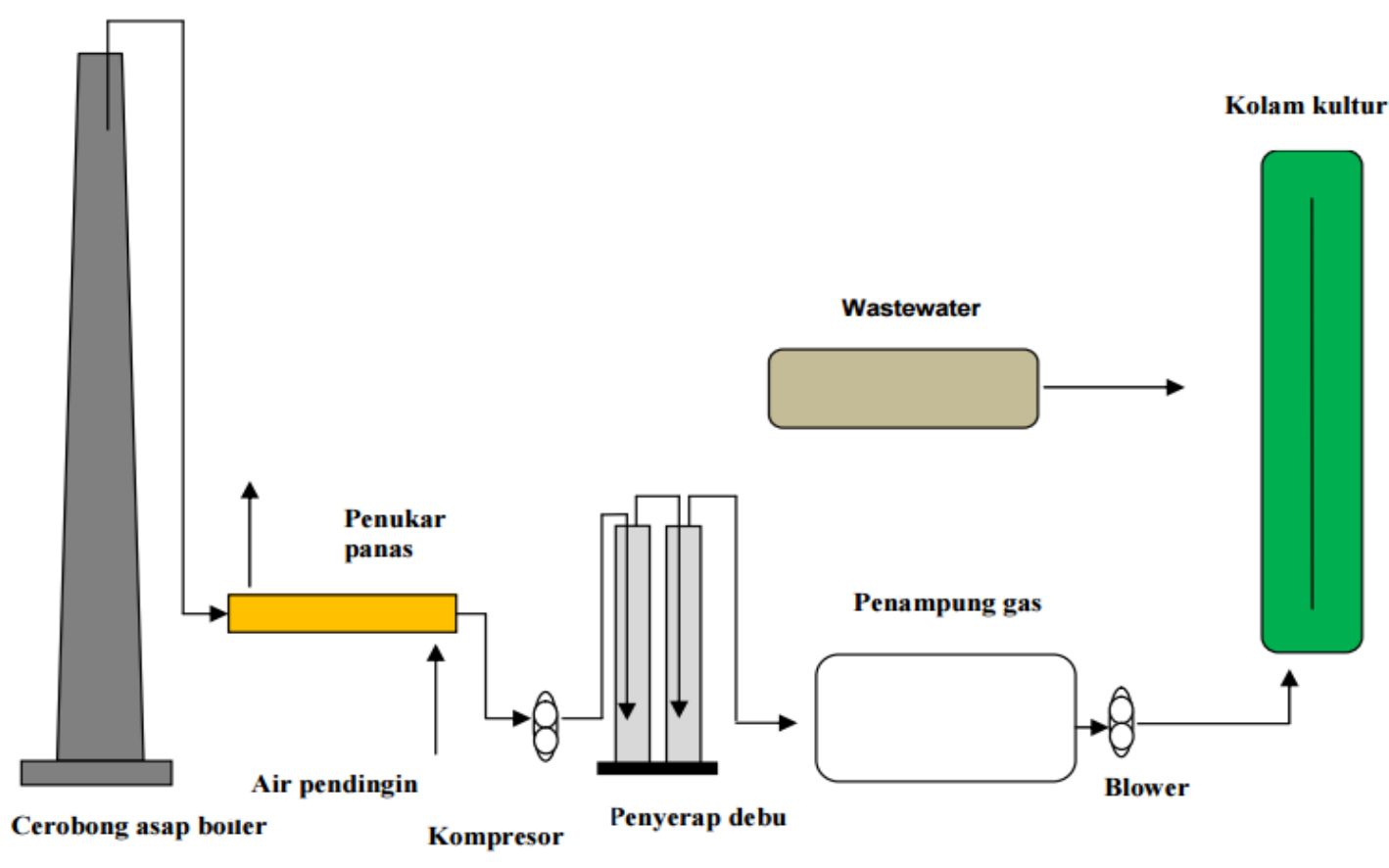

Gambar 6. Diagram pilot scale sistem FBR

\section{POLA PERTUMBUHAN MIKROALGA}

Terdapat beberapa jenis mikroalga yang memiliki potensi digunakan sebagai biota penyerap gas karbon dioksida, misalnya adalah Chlorella vulgaris. Mikroalga hijau jenis ini di negara Jepang dimanfaatkan dalam penanganan medik. Selain itu $C$. vulgaris juga memiliki potensi untuk dimanfaatkan dalam proses produksi bahan bakar bio (biofuel) serta bahan tambahan pangan (food additive). Negara penghasil Chlorella terbesar adalah Jerman, Jepang dan Taiwan (Wikipedia, 2018c). Meskipun C.vulgaris ditemukan pertama kali pada tahun 1890 oleh Martinus Willem Beijerinck, seorang ahli mikrobiologi bangsa Belanda, sebagai mikroalga dengan susunan inti sel yang jelas namun pada awal tahun 1990 diketahui bahwa $C$. vulgaris memiliki 
kandungan protein tinggi oleh ilmuwan bangsa Jerman (Wikipedia, 2018c). Chlorella vulgaris merupakan mikroalga yang tahan kondisi lingkungan kurang baik serta mampu bersaing dengan organisma lain yang populasinya melebihi populasi dari C.vulgaris. Budidaya C.vulgaris untuk menghasilkan berbagai molekul organik seperti lipida, pati dan protein bergantung kepada teknik yang digunakan dalam membangun biomassa sel C.vulgaris tersebut (Safi et al., 2014). Dalam lingkungan yang kurang baik penambahan bobot biomassa C.vulgaris berkurang namun kadar pati dan lipid meningkat
(Prybil et al., 2012). Sedangkan dalam lingkungan yang lebih baik kadar protein meningkat selaras dengan kenaikan bobot biomassa (Chisti 2007). Terdapat sejumlah cara yang dapat diterapkan seperti pemusingan (centrifugation), pembentukan flok (flocculation), penyaringan (filtration) atau pengambangan (floatation) dalam memanen biomassa mikroalga (Lee et al., 2012 dan Cheng et al., 2010). Jika bobot biomassa cukup besar biasanya dengan teknik pemusingan dapat memanen biomassa mikroalga dengan tingkat efisiensi $95 \%$.

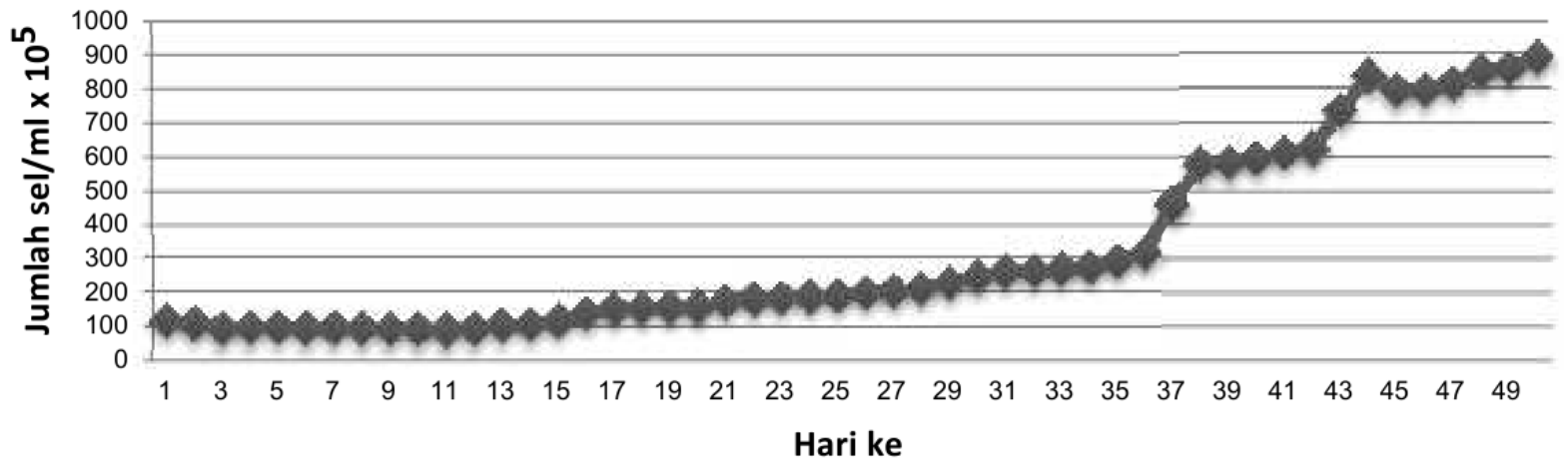

Gambar 7. Grafik pertumbuhan C.vulgaris 


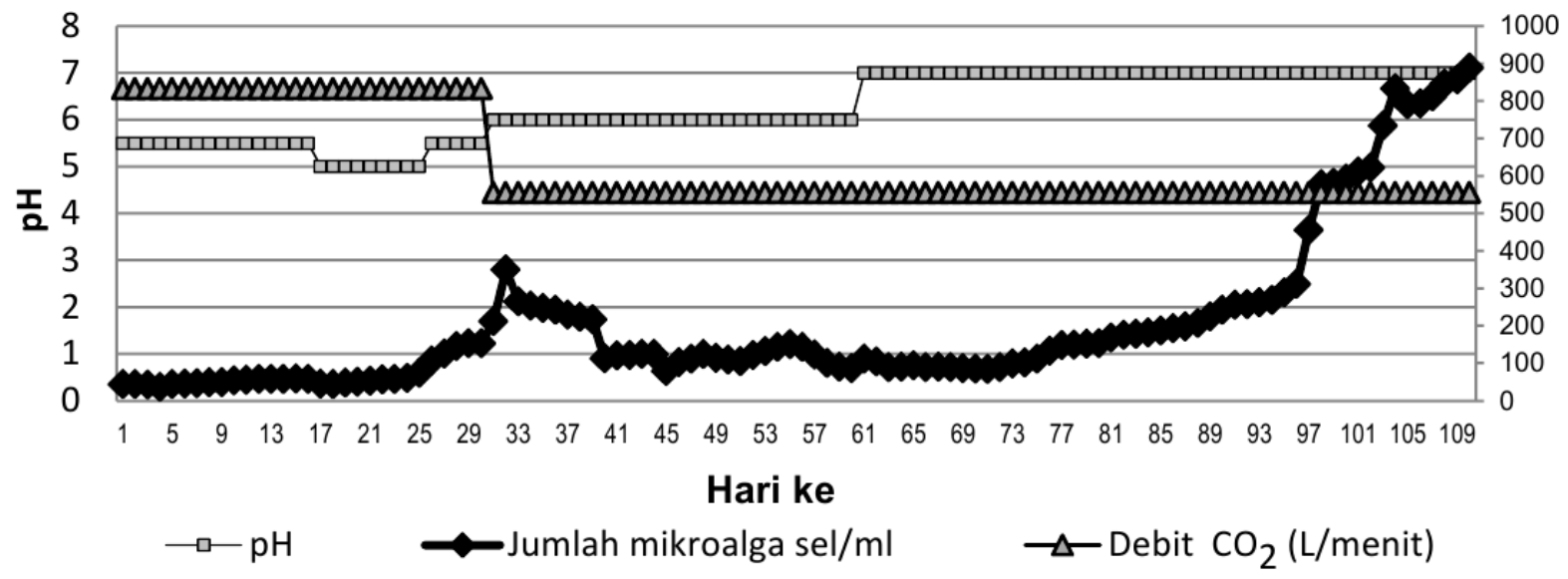

Gambar 8. Grafik pertumbuhan C.vulgaris vs debit $\mathrm{CO}_{2}$

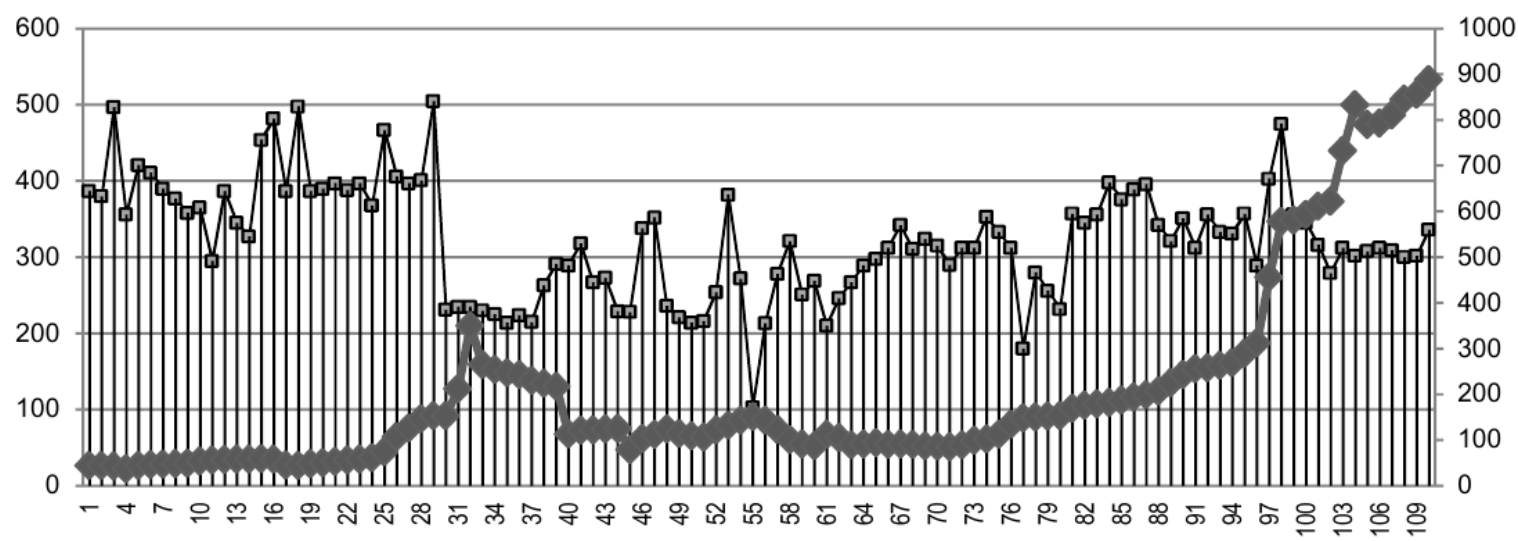

Hari ke

$$
\longrightarrow \text { Intensitas Cahaya (10 x) Lux —umlah mikroalga sel/ml }
$$

Gambar 8. Grafik pertumbuhan C.vulgaris vs intensitas cahaya

Mikroalga jenis lain yang juga memiliki potensi sebagai biota penambat karbon adalah Euglena sp. yang merupakan flagelata sel tunggal eukariotik. Euglena merupakan biota yang dapat bersifat autotroph maupun 
heterotroph dalam mendapatkan energi untuk proses bertumbuh dan berkembang. Spesies Euglena ada yang hidup di perairan tawar maupun payau.

Grafik pertumbuhan mikroalga C.vulgaris (Mulyanto \& Handayani, 2015) pada periode pengamatan sampai dengan 49 hari disajikan pada Gambar 7. Sedangkan pengaruh laju aliran gas $\mathrm{CO}_{2}$ serta kuat penerangan sinar matahari terhadap perumbuhan mikroalga masingmasing ditunjukkan pada Gambar 8 dan 9.

Penambahan jumlah sel mikroalga seiring dengan waktu pada umumnya serupa dengan pola pertumbuhan jasad renik, yakni kinetika pertumbuhan orde pertama (Miao et al., 2012):

$$
\frac{d N}{d t}=\mu N
$$

dengan $\mathrm{N}$ menyatakan populasi mikroalga pada saat $t$ satuan waktu. Tetapan $\mu$ menyatakan laju pertumbuhan khas (specific) untuk kinetika orde pertama yang nilainya tidak bergantung terhadap $\mathrm{t}$ (waktu). Seperti yang tampak pada Gambar 8 dan Gambar 9 pertumbuhan mikroalga dipengaruhi oleh laju umpan gas karbon dioksida serta intensitas sinar cahaya matahari. Penurun laju umpan gas karbon dioksida serta penurunan intensitas sinar cahaya matahari menurunkan laju pertumbuhan sel mikroalga namun sifatnya adalah sementara. Setelah beberapa hari pertumbuhan populasi mikroalga meningkat yang artinya mikroalga sanggup untuk beradaptasi dengan perubahan yang terjadi. Efisiensi penambatan karbon oleh mikroalga selain dipengaruhi oleh konsentrasi karbon yang masuk ke dalam kolam budidaya mikroalga juga dipengaruhi oleh tingkat kepadatan atau populasi mikroalga dalam sistem tersebut. Pengaruh peragaman karbon terhadap produktifitas mikroalga, produksi biomassa $(X)$ dan laju pertumbuhan spesifik $(\mu=K)$ ditunjukkan pada Tabel 1 (Prayitno, 2015; Sydney et al., 2010; Chiu et al., 2008; de Morais \& Costa, 2007). 
Tabel 1. Pengaruh konsentrasi $\mathrm{CO}_{2}$ terhadap pertumbuhan mikroalga

\begin{tabular}{l|l|l|l|l|l|c}
\hline species & $\begin{array}{c}\text { Vol } \\
\text { kerja } \\
(\mathrm{L})\end{array}$ & $\begin{array}{l}\mathrm{CO}_{2} \\
(\%)\end{array}$ & $\begin{array}{l}\boldsymbol{K} \\
(/ \mathrm{hari})\end{array}$ & $\begin{array}{l}\boldsymbol{P}_{\max } \\
(\mathrm{g} / \mathrm{L} / \mathrm{hari})\end{array}$ & $\begin{array}{l}\boldsymbol{X}_{\max } \\
(\mathrm{g} / \mathrm{L})\end{array}$ & $\begin{array}{c}\text { Puncak produksi } \\
\text { (hari ke-) }\end{array}$ \\
\hline Chlorella vulgaris & 8 & 5 & 0,29 & 0,31 & 1,94 & 7 \\
\hline Botryococcus braunii & 8 & 5 & 0,24 & 0,61 & 3,11 & 9 \\
\hline Spirulina platensis & 8 & 5 & 0,22 & 0,73 & 2,18 & 9 \\
\hline Dunaliella tertiolecta & 8 & 5 & 0,21 & 0,42 & 2,15 & 21 \\
\hline Spirulina sp & 1,8 & 0,03 & 0,33 & 0,04 & 0,82 & 21 \\
\hline Spirulina sp & 1,8 & 6 & 0,44 & 0,20 & 3,40 & 21 \\
\hline Scenedesmus obliquus & 1,8 & 0 & 0,15 & 0,04 & 0,31 & 21 \\
\hline Scenedesmus obliquus & 1,8 & 6 & 0,22 & 0,10 & 1,56 & $6-8$ \\
\hline Nannochloropsis oculata & 0,8 & 0,03 & 0,19 & $\mathrm{NA}^{*}$ & 0,27 & $6-8$ \\
\hline Nannochloropsis oculata & 0,8 & 2 & 0,57 & $\mathrm{NA}^{*}$ & 1,28 & \\
\hline
\end{tabular}

$\mathrm{NA}=$ not available (tidak ada data)

Hasil yang serupa perihal pengaruh laju alir (debit) umpan karbon dioksida terhadap pertumbuhan Chlorella ditunjukkan pada Tabel 2 (Rusdiani dkk., 2016). Seperti yang dapat disimak pada tabel tersebut laju alir (debit) injeksi gas $\mathrm{CO}_{2}$ lebih berpengaruh terhadap produktivitas mikroalga dibandingkan dengan laju alir linear fluida dalam sistem FBR tubular column. Dengan melakukan peragaman laju alir injeksi $\mathrm{CO} 2$ dalam kisaran $0,11-0,61 \mathrm{~mL} /$ detik menunjukkan bahwa injeksi $\mathrm{CO}_{2}$ tertinggi memberikan produktivitas mikroalga tertinggi.
Sedangkan peragaman laju alir linear fluida dalam kisaran $14-33 \mathrm{~cm} /$ detik memberikan produktifitas mikroalga terbaik pada laju alir linear $23 \mathrm{~cm} /$ detik. Pada Tabel 2 tersebut juga tampak bahwa pengukuran pada sore hari (pukul 15:00) memberikan angka produktifitas lebih tinggi daripada pengukuran pada pagi hari (pukul 10:00). Hal ini menunjukkan bahwa proses sintesis biomassa terus berlangsung hingga sore hari sepanjang terdapat berkas cahaya UV sinar matahari. Hal ini konsisten untuk seluruh pengamatan yang dilakukan. 
Tabel 2. Pengaruh debit umpan $\mathrm{CO}_{2}$ terhadap produktivitas mikroalga

\begin{tabular}{|c|c|c|c|c|c|}
\hline \multirow{2}{*}{ Var } & \multirow{2}{*}{$\begin{array}{c}\text { Laju Alir } \\
\text { Injeksi } \mathrm{CO}_{2} \\
\text { (ml/detik) }\end{array}$} & \multirow{2}{*}{$\begin{array}{c}\text { Kecepatan } \\
\text { Aliran } \\
\text { Fluida } \\
\text { (cm/detik) }\end{array}$} & \multicolumn{3}{|c|}{$\begin{array}{l}\text { Produktivitas Mikroalga } \\
\text { (gram/liter) }\end{array}$} \\
\hline & & & 10.00 & 15.00 & $\begin{array}{l}\text { Rata- } \\
\text { Rata }\end{array}$ \\
\hline 1 & 0,54 & 17 & 0,1933 & 0,3267 & 0,2600 \\
\hline 2 & 0,36 & 33 & 0,2125 & 0,2867 & 0,2617 \\
\hline 3 & 0,11 & 23 & 0,1850 & 0,3450 & 0,2650 \\
\hline 4 & 0,36 & 14 & 0,2650 & 0,3350 & 0,3000 \\
\hline 5 & 0,61 & 23 & 0,3250 & 0,4050 & 0,3650 \\
\hline 6 & 0,18 & 30 & 0,2950 & 0,3900 & 0,3425 \\
\hline 7 & 0,54 & 30 & 0,2650 & 0,3650 & 0,3150 \\
\hline 8 & 0,36 & 23 & 0,2000 & 0,3650 & 0,2850 \\
\hline 9 & 0,18 & 17 & 0,1300 & 0,1300 & 0,1500 \\
\hline
\end{tabular}

\section{ANALISIS ALIRAN MATERI}

Analisis Aliran Materi (Material Flow Analysis) atau MFA adalah kajian sistematik aliran dan simpanan bahan dalam suatu sistem yang didefinisikan secara ruang dan waktu (Brunner \& Rechberger, 2005). Terminologi yang lebih sempit menggunakan istilah Analisis Aliran Bahan (Substance Flow Analysis) atau SFA. Kata Materi (Material) dalam MFA lebih luas pengertiannya daripada kata Bahan (Substance) dalam SFA. Kata 'materi" meliputi bahan dan barang sedangkan kata "bahan" biasanya merujuk hanya kepada bahan kimia. Konsep MFA memadukan dua prinsip sains yang telah mapan, yakni pendekatan sistem dan kesetaraan massa (Wikipedia, 2018d). Penerapan konsep MFA dapat mencakup kajian dalam satu bagian dari unit proses sebuah perusahaan sampai dengan lintas perusahaan hingga lintas lintas wilayah. Oleh sebab itu dalam menggunakan MFA batasan (boundary) harus didefinsikan dengan jelas. Untuk FBR yang menjadi batasan adalah sistem skala pilot sebagaimana ditunjukkan pada Gambar 6 di atas. 
Aliran massa karbon sebagaimana dinyatakan dalam diagram pada Gambar 6 berawal dari dalam kolom cerobong setinggi $10 \mathrm{~m}$ kemudian dialirkan menuju bak penampungan gas. Sebelum masuk ke dalam bak penampungan aliran gas harus diturunkan suhunya dengan menggunakan sistem penukar panas (heat exchanger) untuk mencapai suhu udara luar (ambient). Setelah melalui saringan penahan partikulat gas masuk ke dalam bak penampung gas yang dari sini kemudian dialirkan ke dalam kolam kultur mikroalga dengan debit yang dikendalikan dengan pompa. Aliran massa karbon yang diperhitungkan memenuhi persamaan neraca massa berikut ini:

$$
\frac{d M_{C-\text { in }}}{d t}=\frac{d M_{C-\text { out }}}{d t}+\frac{d M_{b}}{d t}+\frac{d M_{r}}{d t}
$$

Dengan $\mathrm{Mc}_{\text {-in }}$ dan $\mathrm{Mc}_{\text {-out }}$ menyatakan massa karbon masuk ke dan keluar dari dalam kolam budidaya mikroalga, $\mathrm{Mb}$ menyatakan massa karbon yang ditambat (sequestered) oleh mikroalga sedangkan Mr menyatakan massa karbon yang keluar dari sistem kolam karena proses pernafasan (respiration) oleh mikroalga. Jadi $\mathrm{Mb}$ adalah indikasi akumulasi atau penimbunan karbon yang semula merupakan bagian dari gas karbon dioksida menjadi karbon yang merupakan bagian dari sel mikroalga.

Karakteristik air limbah yang digunakan sebagai medium bagi mikroalga untuk pertumbuhan disajikan pada Tabel 3 . Pada tabel tersebut diinformasikan data pada awal (hari ke-0) sebelum mikroalga memanfaatkan zat hara (nutrient) yang terdapat dalam air limbah dan hari ke-10 setelah mikroalga bertumbuh dan berkembang dalam medium air limbah tersebut. Efisiensi terendah penurunan konsentrasi cemaran (pollutant) adalah $62 \%$ untuk sulfat dan tertinggi adalah $84 \%$ untuk kebutuhan oksigen kimia (chemical oxygen demand atau COD). Nilai tersebut tidak jauh berbeda dengan fosfat (81\%), potasium (83\%) serta kebutuhan oksigen biologis (biological oxygen demand atau BOD) yang besarnya $83 \%$. Sedangkan kemampuan serap mikroalga terhadap $\mathrm{CO}_{2}$ sebagai pengaruh dari peragaman debit emisi gas $\mathrm{CO}_{2}$ disajikan pada Tabel 4. 
Tabel 3. Pengamatan parameter cemaran (pollutant)

\begin{tabular}{lccc}
\hline \hline \multirow{2}{*}{ Parameter } & \multicolumn{2}{c}{$\begin{array}{c}\text { Pengukuran hari ke- } \\
(\mathrm{mg} / \mathrm{L})\end{array}$} & Efisiensi (\%) \\
\cline { 2 - 3 } & 0 & 10 & \\
\hline Klorida & 97,1 & 30,9 & 68 \\
Nitrat & 1,9 & 0,4 & 77 \\
Fosfat & 49,2 & 9,2 & 81 \\
Potasium & 13,4 & 2,2 & 83 \\
Sulfat & 11,2 & 4,2 & 62 \\
COD & 45 & 7 & 84 \\
BOD & 38 & 6 & 83 \\
pH & 7,5 & 6 & - \\
\hline
\end{tabular}

(Sumber: Adimulyanto \& Handayani, 2015)

Tabel 4. Perhitungan kemampuan menyerap milroalga terhadap $\mathrm{CO}_{2}$

\begin{tabular}{|c|c|c|c|c|c|c|c|c|}
\hline \multirow[b]{2}{*}{$\begin{array}{c}\text { Period } \\
\mathrm{e}\end{array}$} & \multirow[b]{2}{*}{$\begin{array}{l}\text { Debit } \\
(\mathrm{L} / \mathrm{min} \\
\quad)\end{array}$} & \multicolumn{2}{|c|}{ Volume $\mathrm{CO}_{2}(\%)$} & \multicolumn{4}{|c|}{ Serapan $\mathrm{CO}_{2}$} & \multirow{2}{*}{$\begin{array}{c}\text { Biomass } \\
\text { a } \\
\text { maksimu } \\
\mathrm{m}(\mathrm{mg} / \mathrm{L}) \\
\end{array}$} \\
\hline & & $\begin{array}{c}\text { Masuka } \\
\mathrm{n}\end{array}$ & $\begin{array}{c}\text { Keluara } \\
\mathrm{n}\end{array}$ & $\begin{array}{c}\% \\
\text { volum } \\
\mathrm{e}\end{array}$ & $\begin{array}{c}\mathrm{L} / \mathrm{ja} \\
\mathrm{m}\end{array}$ & $\begin{array}{c}\mathrm{g} / \mathrm{L} / \mathrm{ha} \\
\mathrm{ri}\end{array}$ & $\begin{array}{c}\text { Efisiensi( } \\
\%)\end{array}$ & \\
\hline I & 6,7 & 5,5 & 0,4 & 5 & $\begin{array}{c}160 \\
4\end{array}$ & 0,3 & 91 & 0,15 \\
\hline II & 4,5 & 5,5 & 0,4 & 5,2 & $\begin{array}{c}107 \\
6\end{array}$ & 0,2 & 96 & 0,86 \\
\hline
\end{tabular}


Tabel 5. Kisaran kandungan minyak dalam berbagai spesies mikroalga

\begin{tabular}{ll}
\hline Microalga & Oil content (\% dry wt) \\
\hline Botryococcus braunii & $25-75$ \\
Chlorella sp. & $28-32$ \\
Crypthecodinium cohnii & 20 \\
Cylindrotheca sp. & $16-37$ \\
Dunaliella primolecta & 23 \\
Isochrysis sp. & $25-33$ \\
Monallanthus salina & $>20$ \\
Nannochloris sp. & $20-35$ \\
Nannochloropsis sp. & $31-68$ \\
Neochloris oleoabundans & $35-54$ \\
Nitzschia sp. & $45-47$ \\
Phaeodactylum tricornutum & $20-30$ \\
Schizochytrium sp. & $50-77$ \\
Tetraselmis sueica & $15-23$ \\
\hline
\end{tabular}

\section{NILAI TAMBAH TEKNOLOGI}

Dari Tabel 4 di atas dengan menggunakan laju alir (debit) CO2 sebesar 6,7 L/menit akan menghasilkan biomassa mikroalga C. vulgaris sebesar $0,15 \mathrm{mg} / \mathrm{L}$. Hal ini lebih rendah daripada laju alir (debit) $\mathrm{CO} 2$ sebesar 4,5 L/menit yang menghasilkan biomassa mikroalga $0,86 \mathrm{mg} / \mathrm{L}$. Bila menggunakan basis $1000 \mathrm{~L}$ kolam kultur tipe raceway maka maksimum $\mathrm{CO} 2$ yang dapat ditambat selama setahun adalah sebesar:

$$
M_{b}=\left(0,3 \frac{g}{L \text { hari }}\right)(1000 \mathrm{~L})(365 \text { hari })\left(\frac{1 \text { ton }}{10^{6} \mathrm{~g}}\right)=0,11 \text { ton }
$$


Apabila dua kolam raceway dioperasikan sesuai dengan jumlah cerobong yang beroperasi maka bobot karbon yang dapat ditambat adalah 0,22 ton/tahun dengan bobot biomassa mikroalga yang dihasilkan sebesar 109,5 kg/tahun. Jika perhitungan yang sama dilakukan untuk laju alir 4,5 $\mathrm{L} /$ menit maka akan memberikan $\mathrm{Mb}=0,14$ ton namun dengan bobot biomassa yang lebih tinggi, yakni 627,8 kg/tahun.

\section{KETERBATASAN PENERAPAN}

Sampai dengan saat ini masih belum diperoleh teknik yang memadai untuk dapat menangani laju emisi gas karbon dioksidayang cukup tinggi dari menara gas buang industri. Peningkatan laju alir gas berpotensi menurunkan konversi karbon anorganik menjadi komponen karbon biologik mikro alga. Meningkatkan laju alir dari 1,5 menjadi 2,0 L/min menurunkan efisiensi FBR sebesar 34,8\% (Santoso et al., 2011). Hal ini disebabkan proses penambatan karbon anorganik menjadi karbon organik oleh sistem biologik berlangsung lambat. Selain itu juga sangat dipengaruhi oleh intensitas sinar matahari serta unsur hara pembatas seperti nitrogen dan fosfor. Pertumbuhan biomassa mikroalga secara teori $\mathrm{Y}_{\mathrm{xE} \text { (obs) }}$ dapat dihitung dengan menggunakan persamaan berikut (Kliphuis et al., 2011):

$$
Y_{x E(\text { obs })}=\frac{C U R * M_{\text {biomass }}}{P F_{\text {in }}}
$$

dengan CUR menyatakan Carbon Uptake Rate, $\mathrm{M}_{\text {biomass }}$ adalah biomassa mikroalga, sedangkan $\mathrm{PF}_{\text {in }}$ adalah photon flux. Nilai CUR dihitung dari persamaan:

$$
C U R=\frac{n_{\text {gas,out }}\left(x_{\mathrm{CO}_{2}, \exp }-x_{\mathrm{CO}_{2}, \mathrm{wb}}\right)}{100}
$$

di mana ${ }^{\mathrm{n}}$ gas adalah jumlah mol gas per satuan waktu (mmol/jam), Xco2 adalah fraksi mol.

\section{KESIMPULAN}

Menyimak hasil perhitungan di atas maka dengan menimbang harga satuan untuk karbon yang berada dalam kisaran USD 2 - 20 per ton maka opsi memanen bobot biomassa mikroalga lebih menguntungkan. Perlu perekayasaan teknologi penambatan karbon (carbon sequestration) yang lebih efisien agar dengan volume fluida yang lebih kecil dapat dilakukan pemanenan biomassa dengan frekuensi yang lebih banyak dengan periode waktu tinggal (retention time) yang pendek. Jika hal ini diperoleh maka potensi penambatan karbon serta produksi biomassa mikroalga akan meningkat sedemikian serupa sehingga 
dari aspek ekonomis memberikan peningkatan yang lebih baik pula. Dari hasil pemanenan mikroalga tersebut dapat diproses lebih lanjut untuk menghasilkan pewarna bio (biopigment), bahan bakar bio (biofuel) maupun produk lainnya yang berbasis mikroalga. Kandungan minyak dalam mikroalga beragam sebagaimana disajikan pada Tabel 5. Untuk mikroalga jenis Chlorella sp memiliki kandungan minyak dalam kisaran 28 - 32\% (Ma'rufatin, 2016; Chisti, 2007). Meski pada saat ini opsi untuk dimasukkan ke dalam ranah Mekanisme Pembangunan Bersih (Clean Development Mechanism) melalui perdagangan karbon (carbon trade) tampaknya belum menguntungkan akan tetapi dari segi PROPER yang diterapkan oleh Pemerintah Indonesia serta peluang untuk menyatakan diri sebagai perusahaan berwawasan lingkungan melalui ISO14024 tentang Ecolabel bagi perusahaan yang ingin go international penerapan FBR akan memberikan daya ungkit yang cukup berarti agar bisa mendapatkan citra perusahaan "GREEN COMPANY".

\section{DAFTAR PUSTAKA}

Brunner P. H. \& H. Rechberger. 2005. Practical Handbook of Material Flow Analysis. Taylor \& Francis e-Library
Cheng Y. L., Y. C. Juang, G. Y. Liao, S. H. Ho, K. L. Yeh, C. Y. Chen, J. S. Chang, J. C. Liu \& D. J. Lee. 2010. Dispersed ozone flotation of Chlorella vulgaris. Bioresource Technology Vol. 101:9092-9096

Chisti Y. 2007. Biodiesel from microalgae. Biotechnology Advances Vol. 25:294-306

Chiu, S.Y., C.Y. Kao, C.H. Chen, T.C. Kuan, S.C. Ong \& C.S. Lin. 2008. Reduction of $\mathrm{CO}_{2}$ by a high-density culture of Chlorella sp. in a semicontinuous photobioreactor. Bioresource Technology Vol. 99:3389-3396

de Morais M. G. \& J. A. V Costa. 2007. Biofixation of carbon dioxide by Spirulina sp. and Scenedesmus obliquus cultivated in a three-stage serial tubular photo-bioreactor. Journal of Biotechnology Vol. 129:439-445

Hindarto D. E. \& A. Samsyanugraha. 2013. Pengantar pasar karbon untuk pengendalian perubahan iklim. Dewan Nasional Perubahan Iklim

Global Greehouse Gas Reference Network. 2018. Trends in atmospheric carbon dioxide. Global Monitoring Division. Earth System Research Laboratory. National Oceanic and Atmospheric Administration

Handayani T., A. Mulyanto \& N. Sopiah. 2014. Penyerapan emisi $\mathrm{CO}_{2}$ oleh mikroalga Euglena sp dengan bioreaktor kolam kultur. Jurnal Ecolab Vol. 8(1):1-10 
Kementerian Lingkungan Hidup dan Kehutanan. 2018. Program Penilaian Peringkat Kinerja Perusahaan Dalam Pengelolaan Lingkungan

URL:

http://www.menlhk.go.id/site/post/11 $\underline{9}$ [Online, diunduh pada 28 November 2018]

Kliphuis A. M., M. Janssen, e. J. van den End, D. E. Martens, R. H. Wijffels. 2011. Light respiration in Chlorella sorokiniana. Journal Applied Phycology Vol. 23:935-947

Lee D. J., G. Y. Liao, Y. R. Chang \& J. S. Chang. 2012. Coagulationmembrane filtration of Chlorella vulgaris. Bioresource Technology Vol. 108:184-189

Ma'rufatin A. 2016. Pengaruh pemanenan mikroalga Chlorella sp. secara kontinyu terhadap pertumbuhannya di dalam fotobioreaktor. Jurnal Rekayasa Lingkungan Vo. 9(1):1930

Miao H., L. Sun, Q. Tian, S. Wang \& J. Wang. 2015. Study on the effect of monochromatic light on the growth of the red tide diatom skeletonema costatum. Optics and Photonics Journal Vol. 2(3):152-156

Mulyanto A. \& T. Handayani. 2015. Fiksasi emisi karbon dioksida dengan kultvasi mikroalga menggunakan nutrisi dari air limbah industri susu. Jurnal Riset Industri Vol. 9(1):13-21

Portal Resmi Pemerintah Kabupaten Sukabumi. 2018. PROPER sebagai instrumen pengendalian pencemaran dan perusakan lingkungan

URL:

https://sukabumikab.go.id/portal/berit a-opd/1739/proper-sebagaiinstrumen-pengendalianpencemaran-dan-perusakanlingkungan.html

[Online, diunduh pada 28 November 2018]

Prayitno J. 2016. Pola pertumbuhan dan pemanenan biomassa dalam fotobioreaktor mikroalga untuk penangkapan karbon. Jurnal Teknologi Lingkungan Vol.17(1):45-52

Prybil P., V. Cepak \& V. Zachleder. 2012. Production of lipids in 10 strains of Chlorella and Parachlorella, and enhanced lipid productivity in Chlorella vulgaris. Applied Microbiology and Biotechnology Vol. 94:549-561

Roser M. \& E. Ortiz-Ospina. 2017. World population growth. Ourworld in Data URL:

https://ourworldindata.org/worldpopulation-growth [Online, diunduh pada 17 November 2018]

Rusdiani R. R., R. Boedisantoso \& M. Hanif. 2016. Optimalisasi teknologi fotobioreaktor mikroalga sebagai dasar perencanaan strategi mitigasi gas $\mathrm{CO}_{2}$. Jurnal Teknik ITS Vol.5(2):F188-F192

Safi C., B. Zebib, O. Merah, P. Y. Pontalier \& C. Vaca-Garcia. 2014. Morpohology, composition, 
production, processing and application of Chlorella vulgaris: $A$ review. Renewable and Sustainable Energy Reviews vol. 35:265-278

Santoso A. D., R. A. Darmawan \& J. P. Susanto. 2012. Mikroalga untuk penyerapan emisi CO2 dan pengolahan limbah cair di lokasi industri. Jurnal Teknologi Lingkungan - Edisi Khusus Hari Bumi:133-140

Santoso A. D., R. A. Darmawan \& J. P. Susanto. 2011. Pengaruh laju alir injeksi gas emisi pada fotobioreaktor terhadap penyerapan $\mathrm{CO}_{2}$ oleh Chlorella sp. Jurnal Teknologi Lingkungan Vol. 12(1):1-6

Sydney E.B., W. Sturm, J.C. de Carvalho, V. Thomaz-Soccol, C. Larroche, A. Pandey \& C.R. Soccol. 2010. Potential carbon dioxide fixation by industrially important microalgae. Bioresource Technology Journal vol.101: 5892-5896
Wikipedia. 2018a. History of climate change science

URL:

https://en.wikipedia.org/wiki/History of climate change science [Online, diunduh pada 19 November 2018]

Wikipedia. 2018b. Kyoto Protocol

URL:

https://en.wikipedia.org/wiki/Kyoto $P$ rotocol

[Online, diunduh pada 20 November 2018]

Wikipedia. 2018c. Chlorella vulgaris

URL:

https://en.wikipedia.org/wiki/Chlorella vulgaris

[Online, diunduh pada 27 November 2018]

Wikipedia. 2018d. Materia Flow Analysis

URL:

https://en.wikipedia.org/wiki/Material flow analysis

[Online, diunduh pada 27 November 2018] 